総

説

\title{
サルモネラ感染症に対する初期感染防御機構
}

水野由美

\section{Host defense mechanisms against Salmonella infection}

\author{
Yumi MizUnO \\ Department of Pediatric Infectious Diseases, Fukuoka Children's Hospital and Medical Center for Infectious Diseases
}

(Received October 25, 2004)

summary

Salmonella is one of the gram negative intracellular pathogens. The immune response to Salmonella includes innate immunity and adaptive immunity. The intestinal epithelium, neutrophil, macrophage, dendritic cell, NK cell, NK T cell and $\gamma \delta \mathrm{T}$ cell take important part in former process, and antigen specific $\mathrm{T}$ cell and $\mathrm{B}$ cell take part in the later process.

Macrophages and dendritic cells increase in number early after Salmonella infection and produce variety of cytokines. Especially, IL-12, IL-15 and IL-18 play important roles in protection against Salmonella infection, proliferation of NK cell, NKT cell and $\gamma \delta$ T cell, producing IFN $-\gamma$, in addition, IL-12 and IL-18 induce IFN- $\gamma$ production by Th1 cells and adaptive immune response.

Key words_— Salmonella infection; intracellular pathogen; Th1 cells; Th1 cytokine; $\gamma \delta \mathrm{T}$ cell

抄 録

サルモネラは細胞内寄生性のグラム陰性桿菌であり，その感染防御には上皮細胞，好中球，マクロファージ，樹 上細胞などが関与する抗原非特異的な自然免疫と抗原特異的 $\mathrm{T}$ 細胞， B 細胞が関与する抗原特異的な獲得免疫に大 きくわけられ，その間に NK 細胞，NKT 細胞， $\gamma \delta \mathrm{T}$ 細胞などが関与する早期誘導反応がある。サルモネラに感染 し増殖したマクロファージ，樹状細胞は多くのサイトカインを産生する。そのサイトカインの中でも $\mathrm{IL}-12$, IL-15, IL-18 は NK 細胞，NKT 細胞， $\gamma \delta$ T 細胞の誘導，IFN- $\gamma$ による早期の病原体の排除に重要であり, IL-12 および IL-18 は樹状細胞による抗原提示に反応した Th1 細胞をはじめとする獲得免疫の誘導に重要な役割を果た す.

\section{I. はじめに}

サルモネラはグラム陰性桿菌に属する細胞内寄生 細菌で，約 2000 の血清型がある。宿主による病原 性の発現の違いがあり，S. typhimurium はマウス にはヒトの typhoid feverに相当する全身感染を起 すが，一般にヒトには胃腸炎をひこおこす。逆に S. typhi はヒトには全身感染をおこすがマウスには 胃腸炎を起こすのみである。サルモネラ感染は急性 胃腸炎と菌血症を伴つたチフス様疾患に分けられる が，この両型に明確に区別できない場合もある. WHO の推定では年間 1600 万人が腸チフスに罹患 しうち 60 万人が死亡しており，未だ死亡率の高い 疾患である.

福岡市立こども病院・感染症センター 小児感染症科
細胞内寄生細菌は食食されたマクロファージ，樹 状細胞内で生存, 増殖することができる宿主の殺菌 機構を回避する種々の特徴を有している. 主として マクロファージ内で増殖するため, 菌体に対する特 異抗体が産生されても作用できず，感染防御には抗 原非特異的な自然免疫のほかに抗原特異的 $\mathrm{T}$ 細胞 による獲得免疫（細胞性免疫防御）が重要な役割を 果たす。抗原特異的 $\mathrm{T}$ 細胞はサイトカインの産生 によりマクロファージを活性化して細胞内殺菌能を 亢進させたり, 感染細胞を直接傷害して, 細胞内寄 生細菌に対する防御を発揮する ${ }^{1)}$. 細胞内寄生細菌 に対する免疫応答の研究には結核菌やリステリアが 広く用いられてきた。しかし, 近年 分子微生物学 の進歩とともにサルモネラの病原性や宿主細胞との 相互作用，免疫応答についての分子学的あるいは免 疫学的研究が進んでいる. サルモネラに対する Th1 


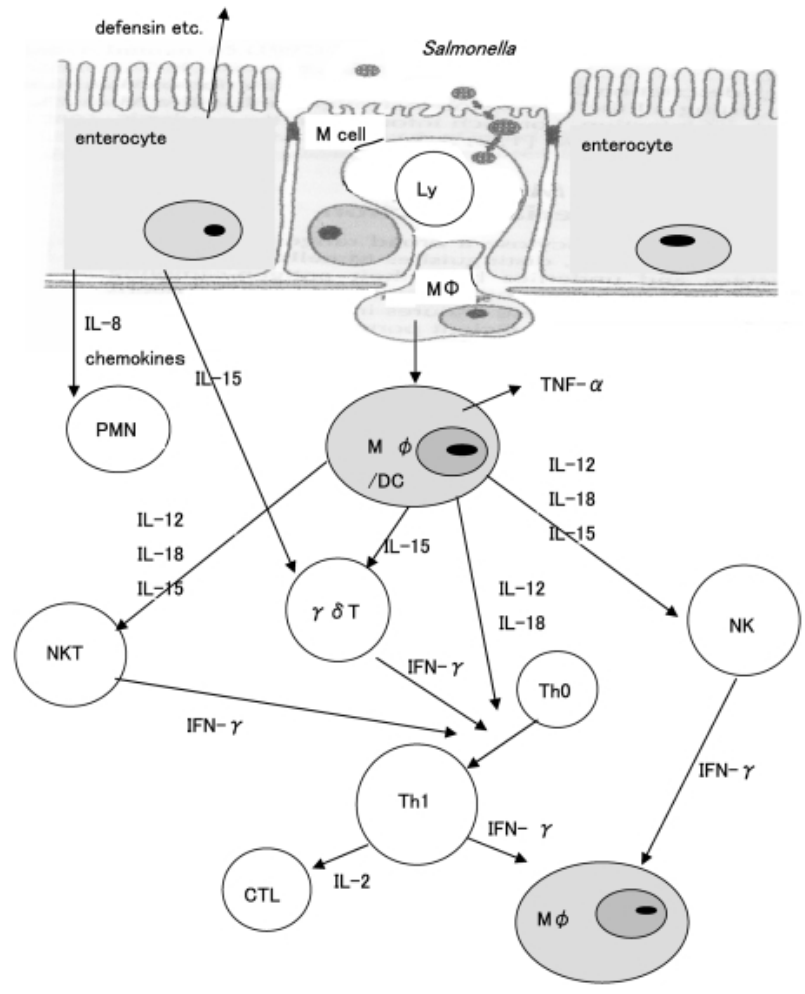

図 1 Th1 細胞・サイトカインを中心といたサルモネラに対 する感染防御機構

サイトカインを中心とした初期感染防御機構につい ての最近の知見を述べる.

\section{II. サルモネラの病原性の分子機構 2}

近年，サルモネラの細胞侵入性を規定する遺伝子 が明らかになっている. サルモネラの染色体には遺 伝子の水平伝播によって獲得された遺伝子群 Salmonella pathogenicity island（SPI）があり，現在 5 つの SPI-1〜 5 が知られている.SPI-1 と SPI-5 は腸炎の発症に, SPI-2 と SPI-3 は全身感染を起す のに必要な蛋白をコードしている，サルモネラの全 身感染は腸管からの侵入後，リンパ管，ついで血中 に入り，腸間膜リンパ節，次いで肝，脾に移行する が，その間，菌はマクロファージ内にあり生体防御 システムによる菌排除から免れている．SPI-2 は細 胞内ファゴゾームに取り込まれることによって発現 し，ファゴゾームーリソソーム融合の抑制，活性酸 素による細胞内殺菌から免れる機能，ファゴゾーム の NADPH oxidase の発現の阻害に関する機能を コードしている。したがって，マクロファージに取 り込まれた後その殺菌作用に抵抗し，肝，脾に広が るために必要な遺伝子である. SPI-1 の領域に存在 する遺伝子は酸素欠乏，高浸透圧など腸管内に似た 条件で発現される，SPI-1 にコードされる蛋白のう
ち type III secretion system により細胞内に注入され るエフェクター分子は Sop (Salmonella outer protein）と呼ばれ腸管上皮内への菌の侵入を助け，腸 管への液体貯留を行い，好中球の浸潤を主体とした 炎症を引き起こす。その他に SPI-1 は侵入に必要 な蛋白 Sip（Salmonella invasion protein）をコード している. SPI のほかに侵入性のサルモネラには大 型のプラスミドがあり，病原性の発揮に関連する spv (Salmonella plasmid virulence) と呼ばれる遺伝 子群が存在する。これらは肝, 脾内での増殖に必要 である。

\section{III. 腸管上皮細胞の免疫応答}

腸管上皮細胞には食物の消化吸収に働く細胞群の ほかに各種 mucins などの粘液構成成分の産生を介 し食物抗原や微生物の生体内への進入を防ぐ物理的 バリアとして機能している。 また腸管上皮細胞は病 原微生物が生体内に進入すると病原体そのものある いはその産生するリポポリサッカライド（LPS）や ペプチドグリカン（PGN）などの菌体成分を認識 して defensin ${ }^{3)}$ などを管腔側に分泌して, 病原微生 物の排除に働いたり， IL-8 などのケモカインを産 生して炎症細胞の感染局所への浸潤を誘導する.

Defensin は腸管の Paneth 細胞のほかに好中球から も産生され DC や T 細胞の走化因子としても働く.

サルモネラが消化管上皮へ侵入する主な侵入門戸 は enterocyte, CD18-expressing phagocyte, M 細胞 (Membranous epithelial cell) である. $\mathrm{M}$ 細胞は小 腸の Peyer 板のようなリンパ組織の上の follicle-associated epithelium（FAE）に存在する4). 管腔側に は不規則な microvilli があり, 側底面側の細胞質は 陥入しリンパ球やマクロファージが入り込んでい る. 病原性による進入門戸の違いについては未だ不 明な点が多い。

サルモネラはグラム陰性菌で外膜構成成分として Lipopolysaccharide（LPS）を有していて，この LPS は CD14 や Toll like receptor（TLR4）を介して 細胞に結合しマクロファージを活性化する5)．サル モネラのフラジェリンに対しては，TLR5 が pattern-recognition receptor として働き腸管上皮を活 性化させる6).

ヒト腸上皮細胞に $S$. dublin，S. typimurium ある いは S. typhi の生菌を感染させた実験では，多くの サイトカインの mRNA の増加が報告されてい る7). 好中球に作用する IL-8, GRO $\alpha / \beta / \gamma$, ENA78, 
G-CSF, GM-CSF, PEEC (pathogen-elicited epithelial chemoatrtactant), CD4 ${ }^{+} \mathrm{Th} 1$ memory $\mathrm{T}$ 細 胞に作用する IP10, Mig, I-TAC (interferon-inducible $\mathrm{T}$ cell chemoattractants)，マクロファージ， T 細 胞に作用する $\mathrm{MCP}-1, \mathrm{MIP}-1 \beta$, 樹状細胞, $\mathrm{T}$ 細胞 に作用する MIP- $3 \alpha$, TRNTES, マクロファージ, B 細胞, 上皮細胞, 線維芽細胞に作用する IL-6, マクロファージ, $\mathrm{T}$ 細胞, 上皮細胞, 線維芽細胞に 作用する $\mathrm{TNF}-\alpha$ などのサイトカインの mRNA の 増加や培養上清中への分泌の増加が報告されてい る7).これらのサイトカインはサルモネラの感染時 に種々の白血球が遊走し, 早期の炎症反応・防御反 応の開始・相互作用することに関与しているものと 考えられている.

\section{IV. 単球/マクロファージ}

単球/マクロファージはサルモネラ感染に対する 宿主の免疫応答で重要な役割を担っている。単球/ マクロファージをサルモネラ生菌あるいはその産物 (LPS, porins, flagellin, cytochalasin D) とともに培 養すると種々のサイトカインの mRNA の発現ある いは分泌の増加が報告されている7). 単球/マクロ ファージからの産生が増加するサイトカインには proinflammatory cytokine としては IL-1, TNF- $\alpha$, IL-6 があり, ケモカインとしては MIP- $1 \alpha$, MIP$1 \beta$, MIP- $2 \alpha, \mathrm{KC}$, hematopoietic growth factor とし ては GM-CSF, 他に IL-12, IL-18 の増加が報告さ れている. IL-12 はサルモネラのマクロファージへ の感染後 p40 subunit が著明に上昇するが, 活性の ある IL-12p70 はわずかに上昇するのみである.

IL-18 は感染直後の短時間増加するがその後減少す る.この IL-12 と IL-18 はサルモネラに対する生 態防御上 重要な働きをする IFN- $\gamma$ の産生を誘導 する.

\section{Dendritic cell}

樹状細胞は自然免疫と獲得免疫の橋渡する抗原提 示細胞として重要な役割を担っている. Peyer 板の リンパ滤胞（the follicle-associated epithelium）で は $\mathrm{CD} 8 \alpha^{-} \mathrm{CD} 11 \mathrm{~b}^{-} \mathrm{DC}$ が $\mathrm{M}$ cell に接近して存在 し，腸管内の細菌を食食している，他の食細胞であ る好中球, マクロファージも感染の際, パイエル板 に浸潤し細菌の uptakeに関与している。 サルモネ ラ感染マウスでは 5 日後には $\mathrm{CD} 8 \alpha^{-}$と $\mathrm{CD} 8 \alpha^{+}$ CD4 ${ }^{-}$DC が脾の red pulp に流入してくるため倍増
するが $\mathrm{CD} 8 \alpha^{+}$および $\mathrm{CD} 8 \alpha^{-} \mathrm{CD} 4-\mathrm{DC}$ の数は変わ らない. $\mathrm{CD} 8 \alpha^{+} \mathrm{DC}$ は $\mathrm{TNF}-\alpha$ を産生しサルモネラ の感染防御に重要であるが $\mathrm{TNF}-\alpha$ 産生細胞数とし てはマクロファージと好中球の方が多い. DC の産 生する TNF- $\alpha$ は局所で作用しオートクラインに働 き, DC の成熟と遊走に作用しているのかもしれな いがサルモネラ感染における DC の産生する TNF$\alpha$ の役割は未だ解明されていない8,9). サルモネラを 感染させたマウスにおいてはその感染経路, 細胞の 採取部位により異なるが 病初期においては, IL12 を産生する DC の明らかな増加はみられない。 脾の DC 上には co-stimulatory factor である CD86, $\mathrm{CD} 80$ および CD40 の発現が増加している.これら の co-stimulatory factor を発現した DC はさらにサ ルモネラ特異的 $\mathrm{CD} 4+$ あるいは $\mathrm{CD} 8^{+} \mathrm{T}$ 細胞を誘 導する8).

\section{VI. 実験動物（マウス）におけるサルモネラに対 する免疫応答}

サルモネラ感染において IFN- $\gamma$ はもっとも研究 されているサイトカインでるが，マウスを用いた実 験で in vivo での種々のサイトカインの関与が明ら かになっている7). マウスを用いた実験の報告では サルモネラの感染後, 種々の臟器で $\mathrm{IL}-1$ と $\mathrm{TNF}-\alpha$ は増加していた. TNF $\alpha$ あるいは IFN- $\gamma$ 対する抗 体を投与したマウスにS. typhimurium を感染させ ると死亡率が上昇し, 逆に $\mathrm{TNF}-\alpha$ あるいは $\mathrm{IFN}-\gamma$ を投与すると減少することより, サルモネラ感染に おける重要性が報告されている，IFN- $\gamma$ は T 細胞, $\mathrm{NK}$ 細胞で産生され, サルモネラを感染させたマウ スの腸管粘膜，パイエル板，腸間膜リンパ節，脾， 肝での mRNA の発現および循環血中での増加が報 告されている. また, IFN- $\gamma$ の中和抗体を投与し たマウスや IFN- $\gamma$ knock-out マウスではサルモネ ラを感染させると脾, 肝での菌の増加し生存率が低 下する．IFN- $\gamma$ は食細胞をはじめ種々の細胞に作 用するが, マクロファージを活性化してその殺菌能 を高めることがサルモネラ感染において最も重要で ある. IFN- $\gamma$ の産生を促進するサイトカインに IL12, IL-18 がありいずれもマクロファージが分泌す る. IL-12 は p 35 と p40 のサブユニットからなり, p35 は恒常的に発現しているが，p40は刺激により マクロファージや樹状細胞からの産生が誘導され, サルモネラの感染後, パイエル板, 腸間膜リンパ 節, 肝, 脾出の発現が増加する. それぞれのサブユ 
ニットは単独では生物学的活性を持たないが へテ ロダイマーを形成し生物学的活性を持つ IL-12p70 となる。 サルモネラ感染マウスに IL-12 中和抗体 を投与すると脾での IFN- $\gamma$ の発現および血清中 IFN- $\gamma$ 濃度が 中和抗体を投与しなかったマウス に比べ低く, 脾の細菌数が増加し, 生存率が低下す るが，IL-12 を投与すると宿主の生存率が上昇する ことより，IL-12 が IFN- $\gamma$ の産生を誘導しサルモ ネラの感染防御に重要な役割を果たす。 IL-12 の機 能には, Th1 細胞の分化, 増殖を誘導, $\mathrm{T}$ 細胞,

NK 細胞からの IFN- $\gamma$ の産生，マクロファージの 活性化などがある。

IL-18 はマクロファージで産生され，Th1 細胞や NK 細胞に作用し IFN- $\gamma$ の誘導作用がある. IL-18 の中和抗体を投与したマウスにサルモネラを感染さ せると IL-12 の場合と同様に肝，脾での菌数が増 加し生存率が低下, INF- $\gamma$ の低下がする.

サルモネラを腹腔内投与すると $\mathrm{T}$ 細胞， $\mathrm{NK}$ 細胞 の growth factor である IL-15 の腹腔内マクロフ アージでの発現が増加し， IL-15 に対する中和抗体 を投与すると脾, 肝, 腹腔の菌数が増加するがこれ は IL-15 抗体により腹腔内へ NK 細胞の influx が 妨げられ，IFN- $\gamma$ が減少することによると考えら れ，IL-15 により誘導された NK 細胞による IFN- $\gamma$ の産生がサルモネラ感染防御に働いていることを示 唆するものである.

サルモネラに感染したマクロファージでは IL-15

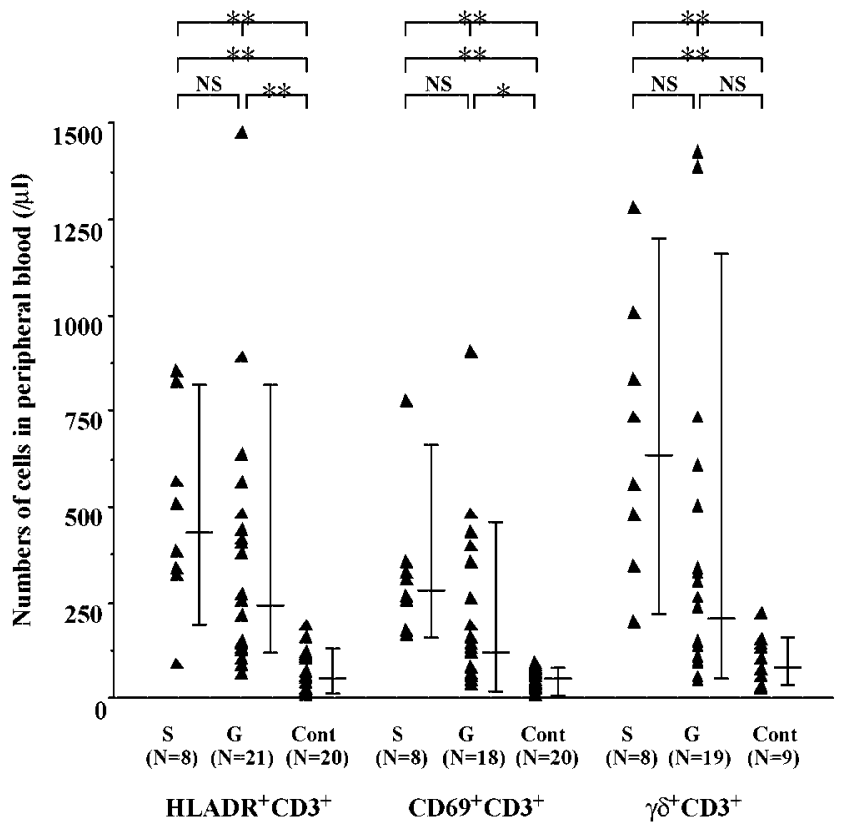

の mRNA の発現及び培養上清中の IL-15 が増加し ており,この IL-15 は $\gamma \delta \mathrm{T}$ 細胞を活性化し IFN- $\gamma$ の産生が誘導される ${ }^{10,11)}$ 。また $\gamma \delta$ (i-IEL) $\mathrm{T}$ 細胞 にも IL-15 の mRNA が発現しており, パラクライ ンに加えオートクラインに働きその増殖を助けるこ とが示唆されている11).

Anti-inflammatory cytokine である IL-4, 1L-10, TGF- $\beta$ に関しては以下のような報告がある。サル モネラを腹腔内に感染させ， IL-4 を中和すると腹 腔内の細菌数が減少し, この時血清中の $\mathrm{INF}-\gamma$ と IL-12 は増加している. サルモネラの感染後 IL-10 は腸管内, 脾, 肝で著明に増加する. TGF- $\beta 1$ をサ ルモネラ感染マウスに投与すると脾・肝での菌数が 減少し, 生存率が増加する. 脾での IFN- $\gamma$ と iNOS の mRNA の発現が増加し血清中の IFN- $\gamma$ と脾のマ クロファージからの NO の産生が上昇している.

\section{VII. ヒトにおけるサルモネラに対する免疫応答}

$\mathrm{IL}-12 \mathrm{R} \beta 1$ 鎖遺伝子の点変異では $\mathrm{IL}-12$ レセプ ターを介した signaling の障害により IL-12 依存性 IFN- $\gamma$ 産生の低下がありマイコバクテリア，サル モネラに対する易感染性を示す ${ }^{12}$. IL-12p40 欠損 症や IFN $-\gamma \mathrm{R} 1, \mathrm{IFN}-\gamma \mathrm{R} 2$ の完全或いは部分欠損患 者でも同様にマイコバアクテリア，サルモネラ感染 を反復することが報告されている13 16).

ヒトにおけるサルモネラに対する感染防御につい ての報告は未だ少ないが，われわれはチフスを含む

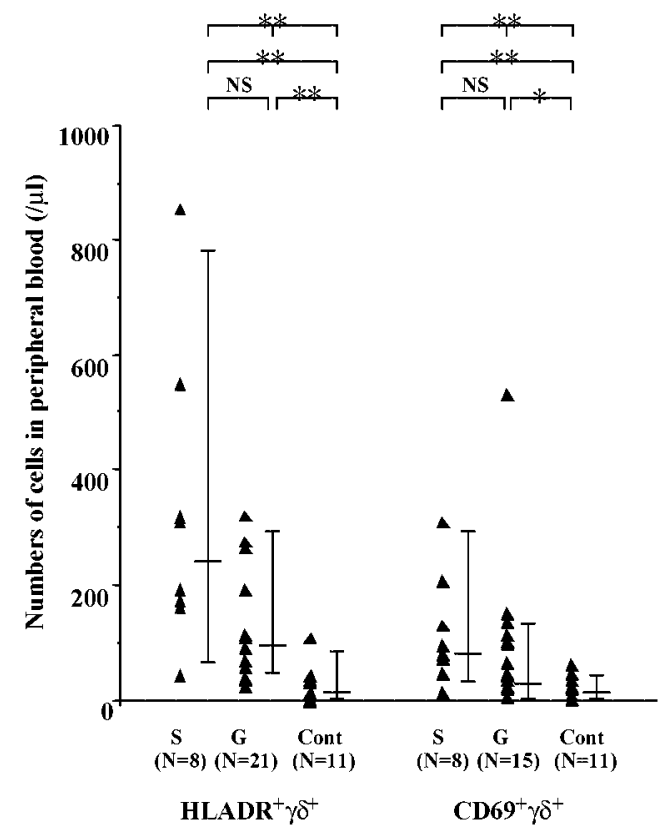

図 2 サルモネラ感染患者の病初期において活性化 (HLA-DR+ あるいは CD69+) T 細胞, 特に $\gamma \delta \mathrm{T}$ 細胞が活性化されていた. $\mathrm{S}$ : 全身型, G : 胃腸炎型, Cont : 対象 

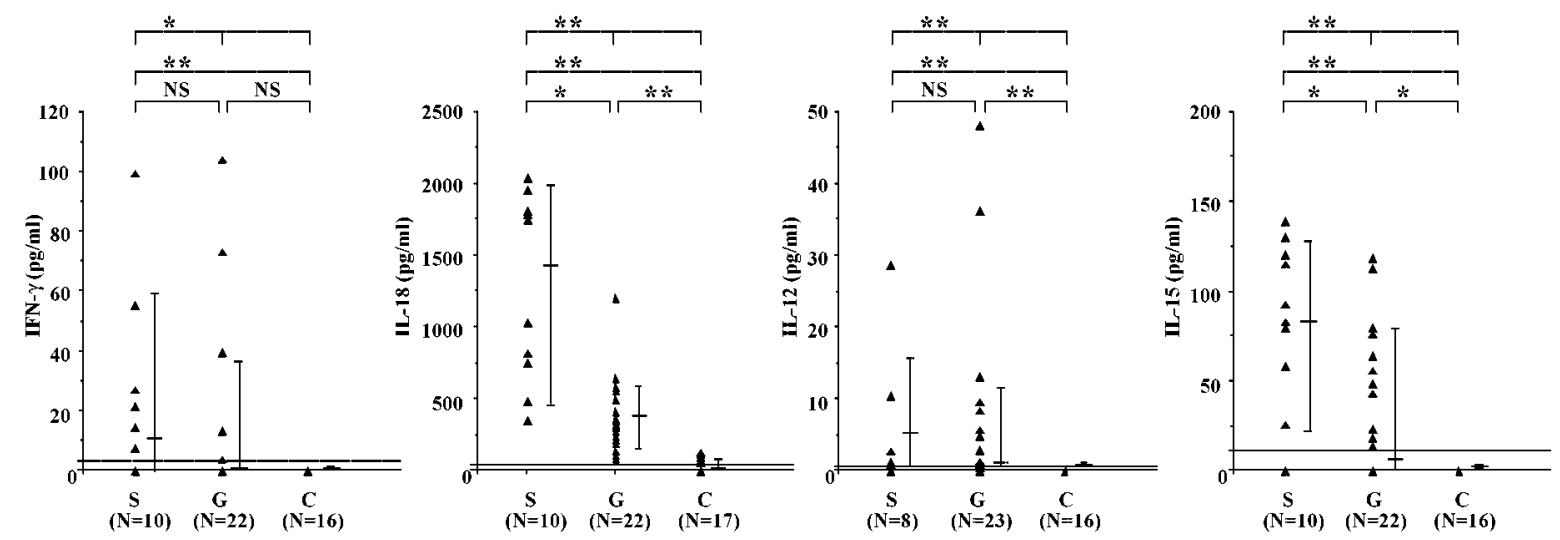

図 3 サルモネラ感染患者の血清中 IFN $\gamma$, IL-12, IL-18, IL-15（最高値）の比較. いずれのサイトカインもサルモネラ感染症患者 で増加していたが，IL-15, IL-18 は全身感染型で胃腸炎型に比較し有意に高值だった. S : 全身型, G : 胃腸炎型, C : 対象
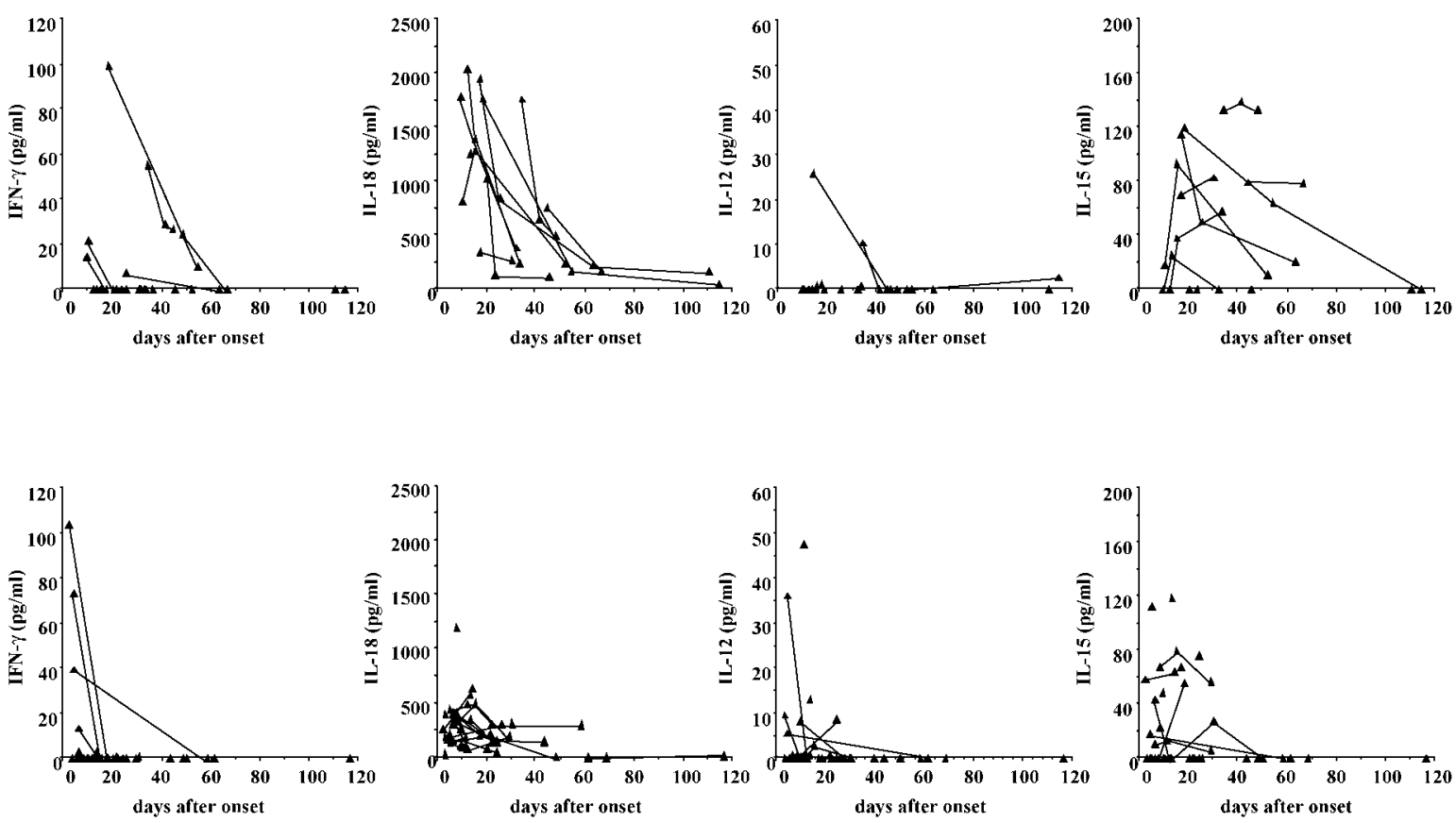

図 4 サルモネラ感染患者の血清中サイトカインの経時変化

IL-15, IL-18 は胃腸炎型に比べ，全身感染型でより高值でより長く持続していた。上段：全身型，下段：胃腸炎型

サルモネラ感染患者のリンパ球 subpopulation およ びサイトカイン産生について検討した ${ }^{17,18)}$.

サルモネラ感染患者の未梢血液中で $\mathrm{V} \gamma 9^{+} \mathrm{Ti} \gamma \mathrm{A}^{+}$ $\gamma \delta \mathrm{T}$ 細胞が増加し17), 病初期において $\mathrm{T}$ 細胞が活 性化されるが特に $\gamma \delta \mathrm{T}$ 細胞が活性化されており (図 2) ${ }^{18)}$ ， ヒト末梢血単核細胞を S. typhi の生菌と 培養すると選択的な $\gamma \delta \mathrm{T}$ 細胞の活性化がみられ た. 患者血清中 IFN- $\gamma, \mathrm{IL}-12, \mathrm{IL}-18, \mathrm{IL}-15$ が増加 し（図 3)，IL-15，IL-18 は胃腸炎型に比べ，全身 感染型でより高值でより長く持続していた（図 4). また末梢血の $\gamma \delta \mathrm{T}$ 細胞および $\alpha \beta \mathrm{T}$ 細胞における IFN- $\gamma$ mRNA の発現を RT-PCR で測定したところ, $\gamma \delta \mathrm{T}$ 細胞にはコントロールに比し有意に多くの
IFN- $\gamma$ mRNA が発現し（図 5), $\gamma \delta \mathrm{T}$ 細胞が産生 する IFN- $\gamma$ がヒトのサルモネラ感染防御において も重要であると考えられた ${ }^{18}$.

サルモネラ感染症は開発途上国では死亡率の高い 感染症であり, また耐性菌の出現, HIV 感染者を はじめとする細胞性免疫不全状態での重症化などが 問題となっている. サルモネラに対する感染防御機 構には未だ不明なことが多く更なる研究がのぞまれ るが, 今後, サルモネラ感染症の治療, より有効な ワクチンの開発を含めた予防法, 他の細胞内寄生細 菌に対する防御機構の解明に重要な役割を果たすも のと考える. 


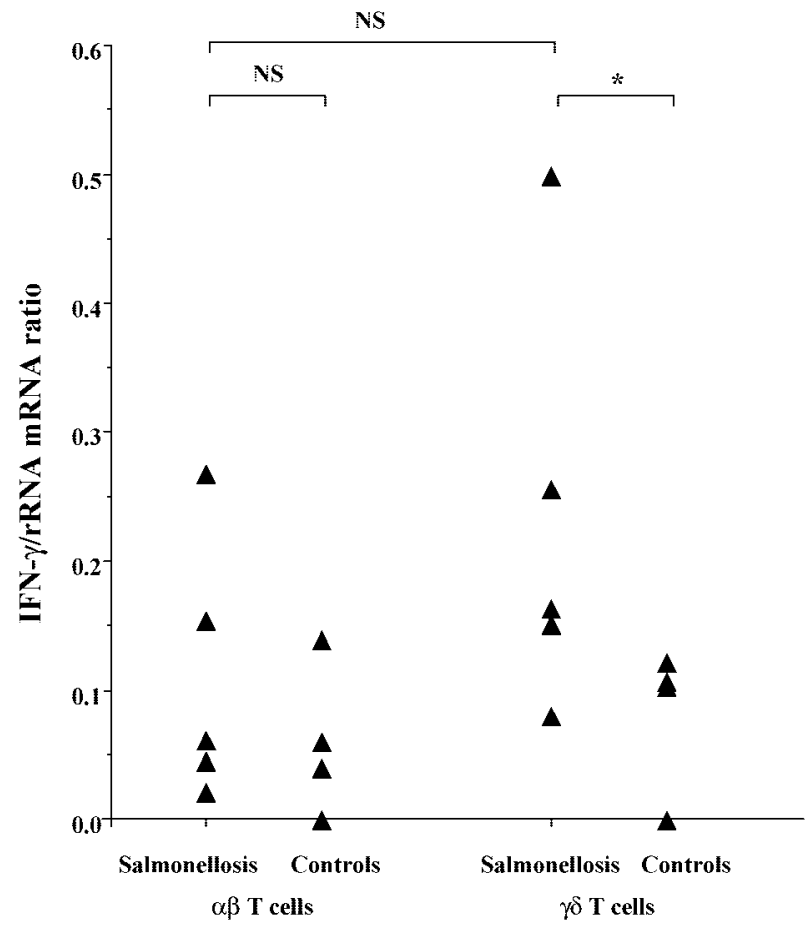

図 5 末梢血の $\gamma \delta \mathrm{T}$ 細胞抢よび $\alpha \beta \mathrm{T}$ 細胞に抢ける IFN- $\gamma$ mRNA の発現. 末梢血の $\gamma \delta \mathrm{T}$ 細胞抢よび $\alpha \beta \mathrm{T}$ 細胞におけ る IFN- $\gamma$ mRNA の発現を RT-PC で測定したところ， $\gamma \delta$ T 細胞にはコントロールに比し有意に多くの IFN $-\gamma$ mRNA が 発現していた。

謝 辞 : 稿を終えるにあたり御指導を承りました 九州大学大学院医学研究院成長発達医学 原寿郎教 授に深謝いたします.

\section{文献}

1）光山正雄 : 感染防御免疫の機構. 吉田眞一, 柳 雄介編, 戸田新細菌学, 改訂 32 版, 南山 堂, 東京 406-423, 2002.

2) 吉田眞一：腸内細菌科の細菌 サルモネラ 属. 吉田眞一, 柳 雄介編, 戸田新細菌学, 改訂 32 版, 南山堂, 東京 558-563, 2002.

3) Granz T.: Defensins : Antimicrobial peptides of innate immunity. Nat Rev Immunol 3 : 710720,2003 .

4) Jepson MA. and M. Ann Clark : The role of M cells in Salmonella infection. Microb Infect 3 : 1183-1190, 2001.

5) Freudedberg MA., et al. : Role of lipopolysaccharide susceptibility in the innate immune response to Salmonella typhimurium infection : LPS, a primary target for recognition of Gramnegative bacteria. Microb Infect 3:1213-
$1222,2001$.

6) Wick MJ : Living in the danger zone : innate immunity to Salmonella. Curr Opin Microb 7 : 51-57, 2004.

7) Eckmann L., Kagnoff MF. : Cytokines in host defense against Salmonella. Microb Infect 3 : 1191-1200, 2001.

8) Sundquist M., Rydström A., Wick MJ. : Immunity to Salmonella from a denritic point of view. Cell Microbio 6 : 1-11, 2004.

9) Wick MJ.: The role of dendritic cells in the immune response to Salmonella. Immunol Lett. 85 : 99-102, 2003.

10) Nishimura H., et al. : IL-15 is a novel growth factor for murine gamma delta $\mathrm{T}$ cells induced by Salmonella infection. J Immunol 156 : 663669, 1996.

11) Inagaki-Ohara $K$, et al. : Interleukin-15 preferentially promotes the growth of intestinal intraepithelial lymphocytes bearing $\gamma \delta \mathrm{T}$ cell receptor in mice. Eur J Immunol 27 : 28852891, 1997.

12) Altare F. et al. : Impairment of mycobacterial immunity in human interleukin-12 receptor deficiency. Science 280 : 1432-1435,1998.

13) Jouanguy E et al. : Partial Interferon-Receptor 1 Deficiency in a Child with Tuberculoid Bacillus Calmette-Guérin Infection and a Sibling with Clinical Tuberculosis. J. Clin. Invest. 100 : 2658-2664, 1997.

14) Altare F. et el. : Inherited Interleukin 12 deficiency in a child with Bacille Calmette-Guérin and Salmonella enteritidis disseminated Infection. J Clin Invest 102 : 2035-2040, 1998.

15) Newport, M. J., et al. : A mutation in the interferon-gamma-receptor gene and susceptibility to mycobacterial infection. N. Engl. J. Med. 335 : 1941-1949, 1996.

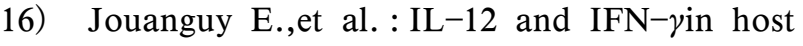
defense against mycobacteria and salmonella in mice and men. Curr Opin Immunol 11 : 346$351,1999$.

17) Hara T., et al. : Predominant activation and expansion of $\mathrm{V} \gamma$ 9-bearing $\gamma \delta \mathrm{T}$ cells in salmonella infection. J Clin Invest 90 : 204-210, 1992.

18) Mizuno Y., et al.: Th1 and Th1-inducing cytokines in Salmonella infection. Clin Exp Immunol. 131 : 111-117, 2003. 